http://dx.doi.org/10.18778/1429-3730.45.02

\title{
Adam Drobniak*
}

\author{
PARTYCYPACJA BIZNESU W PROCESACH \\ REWITALIZACJI MIASTA - PRZYKŁAD KATOWIC
}

\author{
BUSINESS' PARTICIPATION IN THE CITY'S REVITALISATION \\ PROCESSES - THE CASE OF KATOWICE
}

\begin{abstract}
This article focuses on issues related to inclusion of the business sector in the process of revitalization and socio-economic development of a city, in this case the city of Katowice. A broader engagement of the business sector, in the form of investment projects as well as building an ecosystem, determines the success of economic revitalization and the economic viability of crisis areas. The aim of this paper is to present the scale of business engagement in Katowice revitalization projects, as well to indentify the expectations of the business sector in relation to the processes of urban revitalization. In terms of methodology, the study is based on case studies and on focus group interviews (FGI) which were held with selected business sectors in Katowice in 2016.
\end{abstract}

Keywords: revitalisation, participation, business sector

JEL classification: R58

\section{Wstęp}

Artykuł podejmuje problematykę włączenia sektora biznesu w procesy rewitalizacji i rozwoju społeczno-gospodarczego miasta. Współczesne podejście do rewitalizacji - proponowane między innymi w takich dokumentach normatywnych, jak Krajowa Polityka Miejska czy ustawa o rewitalizacji - akcentuje głównie wymiar społeczno-przestrzenny procesów odnowy miejskiej. Wymiar ekonomiczny, $\mathrm{w}$ tym związany z uczestnictwem sektora biznesu, traktowany jest jako element uzupełniający. Niemniej to od szerszego zaangażowania sektora biznesu w postaci projektów inwestycyjnych, a także budowania ekosystemu gospodarczego miasta zależy sukces rewitalizacji oraz stabilność i żywotność ekonomiczna obszarów

* Dr hab. prof. nadzw. Uniwersytet Ekonomiczny w Katowicach, Wydział Ekonomii, Katedra Badań Strategicznych i Regionalnych, e-mail: adr@ae.katowice.pl 
kryzysowych. Celem artykułu jest prezentacja oczekiwań, perspektyw rozwoju biznesu oraz projektów biznesowych wpisujących się w proces rewitalizacji miasta. W warstwie empirycznej badania bazują na zogniskowanych wywiadach grupowych (FGI) prowadzonych z wybranymi branżami biznesu w Katowicach oraz na metodzie studiów przypadków.

\section{Założenia teoretyczne w kontekście rewitalizacji i partycypacji biznesu w procesie rewitalizacji}

Weryfikacja różnorodnych koncepcji odnoszących się do kategorii rewitalizacji wskazuje na wieloaspektowe i wielowątkowe ujęcie badanego pojęcia. W wymiarze koncepcyjnym rewitalizację traktuje się jako długotrwały, zaplanowany proces przywracania lub wprowadzania nowych funkcji na obszarach zdegradowanych $^{1}$. Tego rodzaju przywracanie lub wprowadzanie funkcji powinno stać się nośnikiem ożywienia gospodarczego, społecznego, kulturowego, środowiskowego, przy jednoczesnym porządkowaniu i poprawie jakości przestrzeni miejskiej, wraz z jej fizycznymi elementami². Atrybut kompleksowości procesów rewitalizacyjnych uwidacznia się w ich wielowymiarowości (wymiar: gospodarczy, społeczny, kulturalny, przestrzenny, funkcjonalny) oraz wielopodmiotowości (gmina, jej mieszkańcy, organizacje pozarządowe, biznes lokalny i międzynarodowy, zewnętrzni inwestorzy). Spośród istniejących ujęć koncepcyjnych rewitalizacji jedne uwydatniają konieczność obligatoryjnego ujęcia w jej procesach wszystkich wyżej wskazanych wymiarów, inne wskazują na potrzebę stosownego doboru wymiarów w kontekście istniejącej specyfiki obszaru kryzysowego ${ }^{3}$.

W wymiarze normatywnym pojęcie rewitalizacji można odnaleźć w szeregu dokumentów programujących rozwój kraju ${ }^{4}$, miast i regionów ${ }^{5}$, w tym w ujęciu

${ }^{1}$ J. Parysek, Miasta polskie na przełomie XX i XXI wieku: rozwój i przeksztatcenia strukturalne, Bogucki Wydawnictwo Naukowe, Poznań 2005, s. 166 oraz P. Bielawska-Roepke, Podejście zintegrowane i partycypacja $w$ rewitalizacji zdegradowanych obszarów miejskich, [w:] M. Kowalewski (red.), Zmieniając miasto. Wokót teorii i praktyki rewitalizacji, Wyd. ECONOMICUS, Poznań 2008, s. 15.

${ }^{2}$ S. Kaczmarek, Rewitalizacja terenów poprzemyslowych i nowy wymiar w rozwoju miast, Wydawnictwo Uniwersytetu Łódzkiego, Łódź 2001, s. 16 oraz W. Jarczewski (red.), Przestrzenne aspekty rewitalizacji: śródmieścia, blokowiska, tereny poprzemystowe, pokolejowe i powojskowe, Tom 4. IRM, Kraków 2009, s. 9.

3 J. Parysek, Miasta polskie...

${ }^{4}$ Koncepcja Przestrzennego Zagospodarowania Kraju 2030. KPZK PAN, dokument przyjęty przez Radę Ministrów w dn. 13 grudnia 2011 roku, s. 101 oraz Strategia Rozwoju Kraju 2020. Ministerstwo Rozwoju Regionalnego, Warszawa, wrzesień 2012.

${ }^{5}$ Krajowa Strategia Rozwoju Regionalnego 2010-2020. Ministerstwo Rozwoju Regionalnego, Warszawa 13 lipca 2010 oraz Krajowa polityka miejska. Ministerstwo Infrastruktury i Rozwoju Regionalnego, Warszawa, wrzesień 2015. 
wdrażania funduszy unijnych w perspektywie 2014-2020. Zasadniczo dokumenty normatywne o randze strategii, programów wykorzystują kategorię rewitalizacji w jej koncepcyjnym ujęciu, uwypuklając wielopodmiotowość i wielowymiarowość tego rodzaju procesów. Zapisane w opracowaniach normatywnych kierunki działań związanych z rewitalizacją obejmują szeroki zakres tematyczny, taki jak przykładowo: lepszy stan i dostępność infrastruktury społecznej oraz technicznej (włączając w to budownictwo mieszkaniowe), lepszą integrację transportu publicznego, większe wykorzystanie technologii energooszczędnych, dążenie do przywracania funkcji ekologicznych, a także odtwarzania funkcji kulturalnych, rozwój działalności związanych z turystyką i rekreacją, tworzenie nowoczesnej infrastruktury biznesu (inkubatory, parki technologiczne, centra kongresowe i wystawienniczo-targowe), integracja zarządzania krajobrazem kulturowym odziedziczonym, wyższa aktywność osób wykluczonych, poprawa innowacyjności oraz konkurencyjności gospodarki.

W wymiarze przestrzennym kategoria rewitalizacji odnoszona jest głównie do miast $i$ ich dzielnic, niezależnie od ich rangi demograficznej. Postuluje się, aby procesy rewitalizacji charakteryzowały się także koncentracją przestrzenną poprzez wyznaczanie obszarów kryzysowych determinowanych wysoką kumulacją: depopulacji, niskiej aktywności gospodarczej, niskiej aktywności społecznej, niezadawalającego dostępu do usług publicznych, negatywnych zjawisk środowiskowych, przestrzennych i fizycznych, wysokiego poziomu ubóstwa i koncentracji patologii.

W wymiarze prawnym wprowadzonym przez ustawę o rewitalizacji ${ }^{6}$, a także w założeniach Narodowego Planu Rewitalizacjī można odnaleźć zapisy określające kategorię rewitalizacji, interesariuszy rewitalizacji oraz obszaru zdegradowanego, które zasadniczo są spójne z jej ujęciami koncepcyjnym i normatywnym prezentowanych $\mathrm{w}$ dokumentach strategicznych poziomu krajowego oraz opracowaniach naukowych. Ustawa o rewitalizacji wprowadza dodatkowe terminy odnoszące się do planowania i realizacji procesów rewitalizacyjnych, w tym postaci: Komitetu Rewitalizacji czy Specjalnej Strefy Rewitalizacji. Ujęcie ustawowe kategorii rewitalizacji charakteryzuje głównie społeczno-przestrzenny wymiar, przy w zasadzie niewielkim ujęciu aspektów ekonomicznych, w tym biznesowych determinujących przecież w dużym stopniu poziom „ożywienia” gospodarczego,a w konsekwencji społecznego obszarów zdegradowanych.

Postulat współudziału w procesach rozwoju różnych grup mieszkańców oraz podmiotów związanych z miastem pojawia się w klasycznym już opracowaniu Osborne'a i Gaeblera pt. Rzadzić inaczej ${ }^{8}$ wprowadzającym idee governance oraz New Public Management. W wymiarze partycypacji akcentowana jest konieczność

${ }^{6}$ Ustawa o rewitalizacji, 2015, Dz.U. 2015, poz. 1777 z późn. zm.

7 Narodowy Plan Rewitalizacji 2022. Założenia, Ministerstwo Infrastruktury i Rozwoju, Warszawa 2014.

${ }^{8}$ D. Osborne, T. Gaebler, Rządzić inaczej. Jak duch przedsiębiorczości przenika i przeksztatca administracje publiczną. Media Rodzina, Poznań 2005, s. 343-345. 
decentralizacji władzy oraz przejście od struktury hierarchicznej zarządzania rozwojem - w tym lokalnym - do współudziału i pracy zespołowej. Decentralizacja i współudział mieszkańców i podmiotów miejskich prowadzą w konsekwencji do wygenerowania korzyści związanych z: większą elastycznością w reakcji na zmiany otoczenia, większą efektywnością w zakresie wykorzystania zasobów, większą innowacyjnością oraz lepszym rozpoznaniem potrzeb, mobilizacją lokalnych aktorów ${ }^{9}$.

Zagadnienia partycypacji różnych sektorów, podmiotów i mieszkańców w planowaniu oraz wdrażaniu procesów rozwoju miasta są także wywodzone z koncepcji odnoszących się do współpracy wielosektorowej ${ }^{10}$ lub też partnerstwa i współpracy wielopodmiotowej ${ }^{11}$. Współpraca wielosektorowa czy też wielopodmiotowa jest szczególnie użyteczna przypadku realizacji kompleksowych inicjatyw i projektów, często o charakterze strategicznym, wymagających zgromadzenia szeregu doświadczeń, wiedzy i kompetencji niedostępnych pojedynczym podmiotom.

Rola partycypacji, szczególnie społecznej, w procesach rozwoju miast, w tym ich rewitalizacji czy też szerzej, planowania przestrzennego, jest obecnie dobrze rozpoznana na gruncie teoretycznym, a także prawnym. Podstawowe narzędzie partycypacji wiąże się z konsultacjami społecznymi, które wymagane są przez szereg aktów prawnych (między innymi ustawa o rewitalizacji, ustawa o planowaniu i zagospodarowaniu przestrzennym). Przykładowo ustawa o planowaniu i zagospodarowaniu przestrzennym nakłada obowiązek przeprowadzenia konsultacji społecznych w związku z procedurą uchwalania miejscowego planu zagospodarowania przestrzennego. Natomiast ustawa o rewitalizacji wskazuje na konieczność wykorzystania mechanizmu partycypacji społecznej w procesie przygotowania, prowadzenia i oceny działań rewitalizacyjnych w sposób zapewniający aktywny udział intersariuszy, w tym poprzez udział w konsultacjach społecznych (ustawa o rewitalizacji). W praktyce planowania procesów rewitalizacji w doborze interesariuszy przeważa często „klucz” instytucjonalny oraz społeczny. Oznacza to, że partycypacja realizowana $\mathrm{w}$ formie konsultacji społecznych, adresowana jest głównie do: przedstawicieli jednostek gminnych (m.in.: gminne / miejskie ośrodki pomocy społecznej, powiatowe urzędy pracy, domy kultury, szkoły), reprezentantów organizacji pozarządowych, liderów lokalnych społeczności, mieszkańców, przedstawicieli środowisk kościelnych. W mniejszym stopniu konsultacje społeczne adresowane są do przedstawicieli środowisk biznesowych.

9 Tamże.

10 A. Podgórniak-Krzykacz, Local governance - czyli jak równoważyć zarzadzanie miastem, [w:] Z. Przygodzki (red.), EkoMiasto\#Zarzadzanie. Zrównoważony, inteligentny i partycypacyjny rozwój miasta, Wydawnictwo Uniwersytetu Łódzkiego, Łódź 2010, s. 30-31 oraz E. Boryczka, Partycypacja spoteczna, [w:] A. Nowakowska, Z. Przygodzki, A. Rzeńca (red.), EkoMiasto\#Społeczeństwo. Zrównoważony, inteligentny i partycypacyjny rozwój miasta, Wydawnictwo Uniwersytetu Łódzkiego, Łódź 2010, s. 116117.

${ }^{11}$ A. Drobniak, Projekty strategiczne w mieście poprzemystowym, Wydawnictwo Uniwersytetu Ekonomicznego w Katowicach, Katowice 2012, s. 4951. 
Niemniej to właśnie reprezentanci środowisk biznesowych i prowadzona przez nich działalność gospodarcza w największym stopniu mogą prowadzić do pobudzenia żywotności ekonomicznej obszarów kryzysowych. Żywotność ekonomiczna, zdaniem Rykwerta ${ }^{12}$, na tle zachodzących przemian miejskich jest siłą napędową miasta do zmian w nim zachodzących i kreujących jego wizerunek, dającą perspektywy na dalszy jego rozwój. Kategoria żywotności ekonomicznej wiąże się z szeregiem cech i procesów charakterystycznych dla społeczności aktywnej i rozwijającej się. W tym ujęciu ekonomiczne aspekty rewitalizacji obszarów kryzysowych postrzegane są przez pryzmat ożywienia i aktywizacji działalności różnych jednostek, tj. nie tylko podmiotów gospodarczych, ale grup społecznych, instytucji na rzecz zaspokojenia istniejących i kreowanych nowych potrzeb. Tak rozumiana żywotność ekonomiczna jest zatem bliska pojęciu przedsiębiorczości, odwołującej się do działalności innowacyjnej, czerpiącej z motywacji, kultury, tradycji, otwartości, standardów i powiązań biznesowych.

\section{Założenia metodyczne i wyniki badań}

Skala zaangażowania sektora biznesu w przedsięwzięcia generujące efekty rewitalizacyjne w Katowicach została zidentyfikowana dzięki wykorzystaniu metodyki studiów przypadku. Materiał empiryczny umożliwiający zapoznanie się ze specyfiką i oddziaływaniem poszczególnych projektów biznesowych został zgromadzony w ramach autorskich prac nad szerszymi koncepcjami rewitalizacji Katowic $^{13}$. Uzupełniające narzędzia badawcze dla każdego ze wskazanych projektów biznesowych to: analiza dokumentów, analizy przestrzenno-ekonomiczne związane z wyznaczeniem obszarów kryzysowych, wizyty studyjne.

Zogniskowane wywiady grupowe (FGI, Focus Group Interview) przeprowadzono z przedstawicielami kluczowych, z punktu widzenia rozwoju gospodarczego Katowic, branż obejmujących: sektor nowoczesnych usług biznesowych, zieloną gospodarkę, sektor ICT i branże kreatywne, medycynę i inżynierię medyczną, sektor małych i średnich przedsiębiorstw oraz rzemiosło, przemysł. Zogniskowane wywiady grupowy $(\mathrm{n}=12)$ prowadzono w czerwcu 2016 oraz wrześniu 2016. Uczestniczyli w nich przedsiębiorcy oraz instytucje reprezentujące ich interesy (samorząd gospodarczy), a także osoby zarządzające firmami (w przypadku dużych przedsiębiorstw). Poza identyfikacją potrzeb sektora biznesu obejmowały również wskazanie determinant ich przyszłego rozwoju, planowanych przedsięwzięć oraz identyfikację projektów możliwych do realizacji wspólnie z Miastem Katowice.

12 J. Rykwert, Pokusa miejsca: przyszłość i przeszłość miasta, Międzynarodowe Centrum Kultury, Kraków 2013, s. 15.

13 A. Drobniak, A. Polko, K. Plac, Analiza społeczno-ekonomiczna Katowic wraz z wyznaczeniem obszarów do rewitalizacji i analiza strategiczną, Miasto Katowice, Katowice 2015. 
W tabeli 1 zaprezentowano syntetyczną informację na temat kluczowych projektów biznesowych generujących efekty rewitalizacyjne zrealizowano w Katowicach. Poza określeniem nazw poszczególnych przedsięwzięć, dokonano ich krótkiej charakterystyki oraz na podstawie przeprowadzonych analizy dokumentów, wizyt studialnych i zogniskowanych wywiadów grupowych (FGI) określono poziom interwencji publicznej wraz z oceną żywotności ekonomicznej w badanych lokalizacjach.

Tabela 1. Syntetyczne zestawienie kluczowych przedsięwzięć rewitalizacyjnych realizowanych przez sektor biznesu w Katowicach

\begin{tabular}{|c|c|c|c|}
\hline $\begin{array}{c}\text { Projekt rewitalizacyjny wraz z syntetyczną } \\
\text { charakterystyką }\end{array}$ & $\begin{array}{l}\text { Funkcje } \\
\text { (dawna/ } \\
\text { obecna) }\end{array}$ & $\begin{array}{c}\text { Ocena } \\
\text { poziomu } \\
\text { interwencji } \\
\text { publicznej }\end{array}$ & $\begin{array}{c}\text { Ocena } \\
\text { żywotności } \\
\text { ekonomicznej }\end{array}$ \\
\hline $\begin{array}{l}\text { Park Przemysłowy i Naukowo-Technologicz- } \\
\text { ny (EURO CENTRUM) } \\
\text { Lokalizacja: Katowice, Ligota } \\
\text { Adaptacja obiektów i terenów po Zakładach } \\
\text { Aparatury Chemicznej WIMACH i fabryce } \\
\text { farb na kompleks obiektów biurowych, w tym } \\
\text { pasywnych }\end{array}$ & $\begin{array}{l}\text { gospodarcza / } \\
\text { gospodarcza, } \\
\text { naukowo- } \\
\text {-badawcza }\end{array}$ & wysoki & wysoka \\
\hline $\begin{array}{l}\text { Górnośląski Park Przemysłowy (GPP) } \\
\text { Lokalizacja: Katowice, Wełnowiec-Józefowiec } \\
\text { Budowa kompleksu budynków biurowych, } \\
\text { w tym pasywnych na terenach poprzemysło- } \\
\text { wych po Hucie Silesia }\end{array}$ & $\begin{array}{l}\text { gospodarcza / } \\
\text { gospodarcza, } \\
\text { naukowo- } \\
\text {-badawcza }\end{array}$ & wysoki & wysoka \\
\hline $\begin{array}{l}\text { Galeria Szyb Wilson } \\
\text { Lokalizacja: Katowice, Janów-Nikiszowiec } \\
\text { Stworzenie prywatnej galerii sztuki oraz cen- } \\
\text { trum biznesu w budynkach poprzemysłowych } \\
\text { wraz z ich adaptacją. }\end{array}$ & $\begin{array}{l}\text { gospodarcza } \\
\text { / kulturalna, } \\
\text { gospodarcza }\end{array}$ & niski & wysoka \\
\hline $\begin{array}{l}\text { Stara Huta } \\
\text { Lokalizacja: Katowice, Wełnowiec-Józefowiec } \\
\text { Adaptacja budynków dawnej huty SILESIA } \\
\text { na potrzeby centrum biznesu }\end{array}$ & $\begin{array}{l}\text { gospodarcza / } \\
\text { gospodarcza }\end{array}$ & niski & wysoka \\
\hline $\begin{array}{l}\text { Browar Mokrskich } \\
\text { Lokalizacja: Katowice, Szopienice } \\
\text { Adaptacja budynków poprzemysłowych na po- } \\
\text { trzeby centrum biznesu }\end{array}$ & $\begin{array}{l}\text { gospodarcza / } \\
\text { gospodarcza }\end{array}$ & niski & wysoka \\
\hline $\begin{array}{l}\text { Unilever } \\
\text { Lokalizacja: Katowice, Szopienice } \\
\text { Skuteczna restrukturyzacja i reindustrializacja } \\
\text { dawnych Śląskich Zakładów Przemysłu Tłusz- } \\
\text { czowego }\end{array}$ & $\begin{array}{l}\text { gospodarcza / } \\
\text { gospodarcza }\end{array}$ & niski & wysoka \\
\hline
\end{tabular}




\begin{tabular}{|c|c|c|c|}
\hline 1 & 2 & 3 & 4 \\
\hline $\begin{array}{l}\text { Rockwell Automation } \\
\text { Lokalizacja: Katowice, Szopienice. } \\
\text { Reindustrializacja dzielnicy z wykorzystaniem } \\
\text { lokalizacji firmy z branży automatyki przemy- } \\
\text { słowej, kontroli procesów i informatyki }\end{array}$ & $\begin{array}{l}\text { gospodarcza / } \\
\text { gospodarcza }\end{array}$ & niski & wysoka \\
\hline $\begin{array}{l}\text { Famur } \\
\text { Lokalizacja: Katowice, Piotrowice. } \\
\text { Skuteczna restrukturyzacja i reindustrializacja } \\
\text { przedsiębiorstwa specjalizującego się w produk- } \\
\text { cji maszyn dla potrzeb górnictwa, w tym utwo- } \\
\text { rzenie grupy kapitałowej }\end{array}$ & $\begin{array}{l}\text { gospodarcza / } \\
\text { gospodarcza }\end{array}$ & niski & wysoka \\
\hline $\begin{array}{l}\text { Park Przemysłowo-Technologiczny Porcela- } \\
\text { na Śląska } \\
\text { Lokalizacja: Katowice, Zawodzie } \\
\text { Adaptacja budynków i terenów po dawnych za- } \\
\text { kładach Porcelany Śląskiej na rzecz utworzenia } \\
\text { parku przemysłowo-technologicznego o profilu } \\
\text { „design” }\end{array}$ & $\begin{array}{l}\text { gospodarcza / } \\
\text { gospodarcza, } \\
\text { kulturalna, } \\
\text { edukacyjna }\end{array}$ & niski & średnia \\
\hline $\begin{array}{l}\text { CH Dąbrówka - Burowiecka } \\
\text { Lokalizacja: Katowice, Dąbrówka Mała-Zawo- } \\
\text { dzie } \\
\text { Adaptacja powierzchni i budynków po składach } \\
\text { i bazach transportowych na rzecz centrum han- } \\
\text { dlowego oraz strefy biznesu }\end{array}$ & $\begin{array}{l}\text { gospodarcza / } \\
\text { gospodarcza }\end{array}$ & niski & wysoka \\
\hline $\begin{array}{l}\text { CH Silesia - Dębowe Tarasy } \\
\text { Lokalizacja: Katowice, Dąb - Wełnowiec-Józe- } \\
\text { fowiec. } \\
\text { Adaptacja obiektów i terenów po KWK Got- } \\
\text { twald (później Kleofas) na potrzeby centrum } \\
\text { handlowego, budownictwa mieszkaniowego } \\
\text { i działalności usługowej }\end{array}$ & $\begin{array}{l}\text { gospodarcza / } \\
\text { gospodarczo- } \\
\text {-handlowa, } \\
\text { mieszkaniowa }\end{array}$ & niski & wysoka \\
\hline $\begin{array}{l}\text { Fabryczna - Angelius } \\
\text { Lokalizacja: Katowice, Piotrowice } \\
\text { Adaptacja terenu po składowiskach i magazy- } \\
\text { nach na potrzeby m.in. prywatnej kliniki Ange- } \\
\text { lius Provita }\end{array}$ & $\begin{array}{l}\text { gospodarcza } \\
\text { / usługi me- } \\
\text { dyczne }\end{array}$ & niski & wysoka \\
\hline
\end{tabular}

Źródto: opracowanie własne.

Pożądane efekty rewitalizacyjne generowane przez powyższe projekty biznesowe zrealizowane w Katowicach wiążą się z następującymi elementami:

- koncentracja przestrzenna $w$ ramach obszarów kryzysowych - należy zauważyć, iż wszystkie ze wskazanych projektów biznesowych zlokalizowano na obszarach kryzysowych cechujących się negatywnymi zjawiskami społecznymi. 
Dotyczy to szczególnie dzielnic: Wełnowiec-Józefowiec, Janów-Nikiszowiec, Szopienice, Zawodzie, Dąbrówka Mała, Dąb;

- ponowne wykorzystanie terenów i obiektów poprzemysłowych - każdy $\mathrm{z}$ analizowanych projektów biznesowych zlokalizowano na terenach, które w przeszłości wykorzystywano pod działalność górniczą, hutniczą, składowanie;

- zastapienie lub wprowadzenie nowych funkcji - realizacja każdego z projektów doprowadziła do unowocześnienia dotychczasowej funkcji gospodarczej danego obszaru (wzrost konkurencyjności), a w przypadku części z przedsięwzięć nastąpiło wprowadzenie nowych funkcji (kulturalnej, mieszkaniowej, naukowo-badawczej);

- zaangażowanie kapitatu prywatnego w procesy rewitalizacji - większość $\mathrm{z}$ analizowanych projektów biznesowych cechuje niski poziom interwencji publicznej przy dużym zaangażowaniu środków prywatnych.

Wskazane przedsięwzięcia ${ }^{14}$ generujące efekty rewitalizacyjne ${ }^{15}$ obejmują ponadlokalne, często regionalne i międzynarodowe oddziaływania nie tylko w sferze gospodarczej, ale także społecznej, przestrzennej i środowiskowej. Szereg z nich uważa się za projekty flagowe, strategiczne, tj. wpływające w sposób istotny na procesy transformacji Katowic. Skala finansowego zaangażowania sektora biznesu w tego rodzaju przedsięwzięcia zdecydowanie przerasta dotychczasowy finansowy udział Miasta Katowice w procesach rewitalizacji.

W tym kontekście rozpoznanie oczekiwań sektora biznesu jawi się jako ważny element procesu partycypacji względem planowania rozwoju i rewitalizacji miasta. W kontekście przeprowadzonych konsultacji z przedstawicielami sektora biznesu można sformułować kilka postulatów determinujących - zdaniem sektora - rozwój gospodarczy na obszarach kryzysowych, odnoszących się do edukacji, mieszkalnictwa, promocji i kreowania Katowic jako lidera przemian, oferty inwestycyjnej, wątków tematycznych rozwoju gospodarczego w połączeniu z przestrzenią miasta, współpracy i sieciowania.

Postulaty sektora biznesu odnośnie edukacji odnoszą się do współpracy biznesu ze szkołami wyższymi w zakresie poprawy nauczania języków obcych, a także włączenia studentów i absolwentów na etapie praktyk studenckich w działalność firm międzynarodowych zlokalizowanych w Katowicach. Postulaty tego rodzaju formułowane są również przez dobrze rozwijające się podmioty branż kreatywnych i sektora ICT. Poza współpracą ze szkolnictwem wyższym, akcentowana jest - szczególnie przez sektor małych i średnich przedsiębiorstw oraz rzemiosło - potrzeba wzmocnienia infrastrukturalnego i programowego szkół zawodowych, w tym funkcjonujących na terenach kryzysowych.

${ }^{14}$ Przedsięwzięcia biznesowe są rozumiane jako projekty inicjowane i realizowane wyłącznie przez sektor biznesu (prywatny) zarówno ze środków własnych, jak i obcych (w tym pochodzących $\mathrm{z}$ funduszy europejskich).

${ }^{15}$ Efekty rewitalizacyjne przedsięwzięć biznesowych definiowane są w kategoriach rezultatów o charakterze zarówno finansowym, jak i pozafinansowym, tj. ekonomicznym, społecznym, technicznym i przestrzennym. 
Obecny dalszy rozwój mikro, małych i średnich firm w dużym stopniu zależy od dostępu do osób posiadających stosowne kwalifikacje zawodowe. Odpowiednie doradztwo zawodowe na poziomie gimnazjum, a także promocja kształcenia dualnego (ścisła współpraca szkół zawodowych i techników z przedsiębiorcami) determinuje dalszą dynamikę rozwoju miasta. Nowe branże przemysłu zlokalizowane w Katowicach (zaawansowany przemysł maszynowy, stalowy, samochodowy, elektrotechniczny) są zainteresowane nawiązaniem bezpośredniej współpracy $\mathrm{z}$ technikami, między innymi w formie klas patronackich oraz realizacji praktyk zawodowych na terenie katowickich przedsiębiorstw.

Postulaty odnośnie mieszkalnictwa akcentują potrzebę rozwoju rynku mieszkań na wynajem dla osób przyjeżdżających do miasta w celach związanych z pracą. Rolą miasta powinna być lepsza koordynacja polityki mieszkaniowej oraz współpraca z przedstawicielami sektora deweloperskiego, w tym lokalizacja inwestycji mieszkaniowych na obszarach kryzysowych.

Postulaty związane z promocja i kreowaniem Katowic jako lidera przemian wskazują na propozycję, aby miasto wspólnie z sektorem biznesu prowadziło szeroko zakrojone działania promocyjne obejmujące różnorodne środki promocji, począwszy od regionalnych, ogólnopolskich i międzynarodowych kampanii reklamowych, skończywszy na udziale w targach ofert inwestycyjnych i pomocy w nawiązywaniu bezpośrednich kontaktów pomiędzy firmami działającymi w Katowicach oraz firmami zagranicznymi. Promocja może być prowadzona wspólnie z wybranymi, nowymi sektorami dynamicznie rozwijającymi się $\mathrm{w}$ Katowicach, $\mathrm{tj} .:$ sektorem nowoczesnych usług biznesowych, medycyną i inżynierią medyczną, sektorem kreatywnym wraz z ICT, rzemiosłem (w połączeniu z lokalnymi produktami, które uzyskały europejski certyfikat produktów regionalnych).

W przypadku oferty inwestycyjnej sektor biznesu oczekuje lepszego, tj. bardziej zróżnicowanego przygotowania oferty inwestycyjnej, czyli nie tylko dla dużych inwestorów zagranicznych, ale także dla mniejszych firm, w tym dla sektora ICT oraz branż kreatywnych, które nie zawsze oczekują najwyższej klasy powierzchni biurowych, zadawalając się w początkowych etapach działalności powierzchnią klasy B, która możne zostać wygospodarowana w ramach obiektów poprzemysłowych oraz istniejącej tkanki miejskiej na obszarach kryzysowych. Pożądanym kierunkiem rewitalizacji jest transformacja byłych obiektów i terenów poprzemysłowych oraz pokolejowych na działalność przemysłów kreatywnych, w tym dobrze rozwiniętego na terenie miasta sektora ICT - tak, jak ma to miejsce między innymi w przypadku wyżej opisanego projektu Parku Przemysłowo-Technologicznego Porcelana Śląska.

Sektor biznesu postuluje także łączenie wątków tematycznych rozwoju gospodarczego z przestrzenia miasta. W tym zakresie biznes oczekuje wskazania kluczowych, przyszłościowych branż, na których powinien w przyszłości opierać się rozwój miasta. W przypadku Katowic biznes postuluje skupienie uwagi między 
innymi na działalności związanej z zieloną gospodarką (budownictwo pasywne, technologie OZE, ekologiczny transport), która powinna skupiać się w określonej przestrzeni miasta, przykładowo przez tworzenie stref przemysłowych czy też przemysłowo-usługowych o wyraźnym profilu gospodarczym.

Istotnym postulatem biznesu pozostaje wspótpraca i sieciowanie kontaktów. Mniejsze podmioty gospodarcze (głównie: sektor małych i średnich przedsiębiorstw, rzemiosło, firmy branż kreatywnych oraz ICT, ale także podmioty sektora nowoczesnych usług biznesowych) oczekują większego zaangażowania miasta w tworzenie warunków umożliwiających nawiązywanie kontaktów biznesowych na poziomie lokalnym i międzynarodowym. Wymiana informacji, doświadczeń, wiedzy pomiędzy różnorodnymi branżami i sektorami funkcjonującymi w mieście postrzegana jest jako możliwość tworzenia nowych usług i produktów w procesie budowania przewag konkurencyjnych. W ramach współpracy i sieciowania kontaktów oczekuje się także od miasta stworzenia tzw. „ścieżki wsparcia” podmiotów gospodarczych, od etapu ich tworzenia aż po długofalowy rozwój.

\section{Podsumowanie i wnioski}

Reasumując wyniki badania dotyczącego partycypacji sektora biznesu w procesach rewitalizacji miasta, można wskazać kilka wniosków ogólnych formułowanych w kategoriach: ożywienia gospodarczego, włączenia sektora biznesu w procesy rewitalizacji miasta oraz oczekiwań i postulatów formułowanych przez sektor biznesu względem procesu rewitalizacji.

Wielowymiarowość procesów rewitalizacji, tj. wymiar: społeczny, ekonomiczny, przestrzenny, środowiskowy, infrastrukturalny, w kontekście ożywienia gospodarczego wymaga znaczącego zaangażowania sektora biznesu. Przykłady projektów biznesowych zrealizowanych w Katowicach wskazują, iż ich skala finansowa i generowane efekty rewitalizacyjne są znaczące zarówno w wymiarze stricte finansowym, jak i tworzonych miejsc pracy, wzrostu konkurencyjności gospodarki, zagospodarowania terenów poprzemysłowych sąsiadujących z obszarami kryzysowymi. Włączenie sektora biznesu w procesy rewitalizacji miasta, w tym dobre rozpoznanie jego potrzeb i oczekiwań stanowi niezbędny warunek odpowiedniego, w tym wielopodmiotowego, zaprogramowania działań i przedsięwzięć wpisanych do lokalnego programu rewitalizacji lub też gminnego programu rewitalizacji.

Postulaty formułowane przez sektor biznesu w trakcie prowadzonych konsultacji, jak dowodzi przykład Katowic, cechuje różnorodny charakter. Biznes zainteresowany jest przede wszystkim współpracą i dbałością miasta o kompetencje zasobów ludzkich (wysoka jakość edukacji). Istotne znaczenie dla rozwoju 
firm posiadają także kierunki rozwoju, jakie wyznacza miasto, w tym określenie branż priorytetowych wraz z tworzeniem miejsc, skupień, stref dla tego rodzaju działalności w przestrzeni, w tym przestrzeniach poprzemysłowych. Istotnym postulatem ze strony sektora biznesu, adresowanym do władz miasta, jest także inicjowanie i prowadzenie dialogu z przedsiębiorcami z różnych branż - w postaci spotkań biznesowych, konsultacji czy też wspólnego przygotowania misji gospodarczych i organizacji spotkań w firmami zagranicznymi.

\section{Bibliografia}

Bielawska-Roepke P., Podejście zintegrowane i partycypacja $w$ rewitalizacji zdegradowanych obszarów miejskich, [w:] M. Kowalewski (red.), Zmieniając miasto. Wokót teorii i praktyki rewitalizacji, Wyd. ECONOMICUS, Poznań 2008, s. 15.

Boryczka E., Partycypacja społeczna, [w:] A. Nowakowska, Z. Przygodzki, A. Rzeńca (red.), EkoMiasto\#Społeczeństwo. Zrównoważony, inteligentny i partycypacyjny rozwój miasta, Wydawnictwo Uniwersytetu Łódzkiego, Łódź 2010, s. 116-117.

Drobniak A., Polko A., Plac K., Analiza spoleczno-ekonomiczna Katowic wraz z wyznaczeniem obszarów do rewitalizacji i analizq strategiczna, Miasto Katowice, Katowice 2015.

Jarczewski W. (red.), Przestrzenne aspekty rewitalizacji: śródmieścia, blokowiska, tereny poprzemystowe, pokolejowe i powojskowe, Tom 4. IRM, Kraków 2009, s. 9.

Kaczmarek S., Rewitalizacja terenów poprzemysłowych i nowy wymiar w rozwoju miast, Wydawnictwo Uniwersytetu Łódzkiego, Łódź 2001, s. 16.

Koncepcja Przestrzennego Zagospodarowania Kraju 2030. KPZK PAN, dokument przyjęty przez Radę Ministrów w dn. 13 grudnia 2011 roku, s. 101.

Krajowa polityka miejska, Ministerstwo Infrastruktury i Rozwoju Regionalnego, Warszawa, wrzesień 2015.

Krajowa Strategia Rozwoju Regionalnego 2010-2020, Ministerstwo Rozwoju Regionalnego, Warszawa 13 lipca 2010.

Narodowy Plan Rewitalizacji 2022. Założenia, Ministerstwo Infrastruktury i Rozwoju, Warszawa 2014.

Nowakowska A., Przygodzki Z., Rzeńca A. (red.), EkoMiasto\#Spoteczeństwo. Zrównoważony, inteligentny i partycypacyjny rozwój miasta, Wydawnictwo Uniwersytetu Łódzkiego, Łódź 2010.

Osborne D., Gaebler T., Rządzić inaczej. Jak duch przedsiębiorczości przenika i przekształca administracje publiczna, Media Rodzina, Poznań 2005, s. 343-345.

Parysek J., Miasta polskie na przełomie XX i XXI wieku: rozwój i przeksztatcenia strukturalne, Bogucki Wydawnictwo Naukowe, Poznań 2005, s. 166.

Podgórniak-Krzykacz A., Local governance - czyli jak równoważyć zarzq̨dzanie miastem, [w:] Z. Przygodzki (red.), EkoMiasto\#Zarządzanie. Zrównoważony, inteligentny i partycypacyjny rozwój miasta, Wydawnictwo Uniwersytetu Łódzkiego, Łódź 2010, s. 30-31.

Przygodzki Z. (red.), EkoMiasto\#Zarządzanie. Zrównoważony, inteligentny i partycypacyjny rozwój miasta, Wydawnictwo Uniwersytetu Łódzkiego, Łódź 2010.

Rykwert J., Pokusa miejsca: przyszłość i przeszłość miasta, Międzynarodowe Centrum Kultury, Kraków 2013, s. 15.

Strategia Rozwoju Kraju 2020, Ministerstwo Rozwoju Regionalnego, Warszawa, wrzesień 2012.

Ustawa o planowaniu i zagospodarowaniu przestrzennym, Dz.U. z 2003, Nr 80, poz. 717 z póź. zm.

Ustawa o rewitalizacji, Dz.U. z 2015, poz. 1777 z póź. zm. 


\section{Streszczenie}

Artykuł dotyczy zagadnień związanych z włączeniem sektora biznesu w proces rewitalizacji i społeczno-ekonomicznego rozwoju miasta. Założeniem badawczym jest postulowane szersze zaangażowanie sektora biznesu w formie projektów inwestycyjnych, jak również tworzenie ekosystemu determinującego rewitalizację ekonomiczną i żywotność ekonomiczną obszarów kryzysowych. Celem artykułu jest zaprezentowanie skali zaangażowania sektora biznesu w projekty rewitalizacyjne w Katowicach, a także identyfikacja oczekiwań sektora biznesu dotyczących procesów miejskiej rewitalizacji. W ujęciu metodycznym badania bazują na metodach: studiów przypadków, zogniskowanych wywiadów grupowych (FGI), które były prowadzone z wybranymi sektorami biznesu w Katowicach w 2016 roku.

Slowa kluczowe: rewitalizacja, partycypacja, sektor biznesu

Numer klasyfikacji JEL: R58 